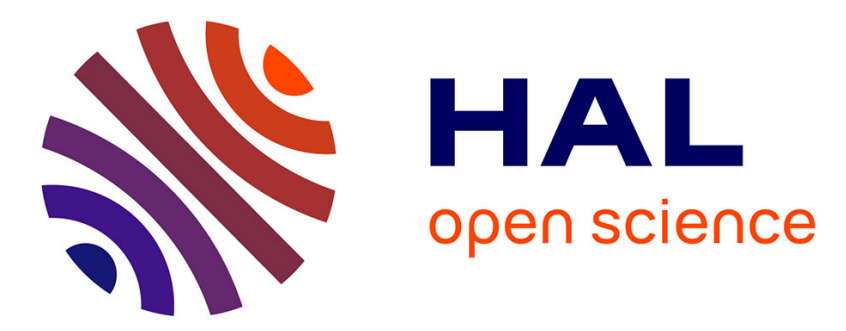

\title{
Study of the effect of hydrothermal process conditions on pasta quality
}

\author{
Zoulikha Maache-Rezzoug, Karim Allaf
}

\section{To cite this version:}

Zoulikha Maache-Rezzoug, Karim Allaf. Study of the effect of hydrothermal process conditions on pasta quality. Journal of Cereal Science, 2005, 41 (3), pp.267-275. 10.1016/j.jcs.2004.10.008 . hal00413517

\section{HAL Id: hal-00413517 \\ https://hal.science/hal-00413517}

Submitted on 4 Sep 2009

HAL is a multi-disciplinary open access archive for the deposit and dissemination of scientific research documents, whether they are published or not. The documents may come from teaching and research institutions in France or abroad, or from public or private research centers.
L'archive ouverte pluridisciplinaire HAL, est destinée au dépôt et à la diffusion de documents scientifiques de niveau recherche, publiés ou non, émanant des établissements d'enseignement et de recherche français ou étrangers, des laboratoires publics ou privés. 
STUDY OF THE EFFECT OF HYDROTHERMAL PROCESS CONDITIONS ON

PASTA QUALITY

\section{Authors:}

\section{Z. Maache-Rezzoug and K. Allaf}

Université de La Rochelle, Laboratoire « Maîtrise des Technologies Agro-Industrielles » Avenue Michel Crépeau, 17042, La Rochelle, France

Author to whom correspondence should be addressed

Z. Maache-Rezzoug

Université de La Rochelle - Pôle Sciences

Laboratoire "Maîtrise des Technologies Agro-Industrielles"

Avenue Michel Crépeau

17042 La Rochelle - France

Tél :

Fax :

(33) 0546458615

e-mail :

(33) 0546458616

zrezzoug@univ-lr.fr 


\begin{abstract}
.
Effect of hydrothermal treatment on the pasting, hydration properties and colour quality of commercial fresh pasta were studied. The Instantaneous Controlled Pressure Drop (DIC) treatment is defined as a hydrothermal treatment that involves a physical modifications at high temperature $\left(<144^{\circ} \mathrm{C}\right)$ and restricted moisture contents $(<30 \%)$ during a very short time $(15-40 \mathrm{sec})$ followed by a rapid pressure drop to a vacuum (50 mbar). Two process variables (steam pressure level and processing time) were investigated using response surface methodology. Steam pressure level had the greatest effect on hydration and pasting parameters. Increasing of pressure level resulted in elevation of mass ratio between cooked and uncooked pasta $\left(\mathrm{W}_{\mathrm{i}} / \mathrm{W}_{0}\right)_{100^{\circ} \mathrm{C}}$ and reduction of optimum cooking time (OCT) for all treated pasta. The OCT of untreated pasta was 7 $\min \left(\mathrm{W} / \mathrm{W}_{\mathrm{o}}=2.4\right)$, while for the same ratio it was less than 1 minute for pasta treated at pressures ranging between 2.5 and 3.5 bar. The viscosity at 10 minutes $\left(\mathrm{V}_{10}\right)$ increased linearly when pressure level increased. $\mathrm{V}_{10}$ was $146 \mathrm{cP}$ for the untreated pasta whereas it reached $2659 \mathrm{cP}$ for the pasta treated at 3.9 bar $\left(144^{\circ} \mathrm{C}\right)$ during 25 second. The cold paste viscosity (CPV) and setback viscosity (SB) decreased when the pressure varied from 1 to 3.9 bar.
\end{abstract}

Keywords: Hydrothermal treatment; Pasta; Hydration properties; RVA 


\section{1: Introduction}

Durum wheat semolina is considered to be the best material for making high quality pasta products. The intrinsic quality attributed to the pasta are influenced primarily by the properties of the protein and starch fraction and by many others factors such as the origin of the semolina (Wood et al., 2001), and the pasta production process (mixing, extrusion and drying conditions) (Kobrehel and Abecassis, 1985; Debbouz and Doetkott, 1996). Starch and proteins are responsible for most desirable characteristics of cereals products. The many textures and culinary quality of pasta are related to the interactions of these two biopolymers in presence of water (Resmini and Pagani, 1983; Güler et al., 2002). The influence of protein on the properties of pasta has received a large research attention (Dexter et al., 1983; Fortini, 1988; Favier, et al., 1996), however, less informations are available on the influence of starch on pasta quality although this macromolecule is the major component of durum wheat semolina (approx. $70 \%)$.

Few studies exist on the application of hydrothermal treatments to the pasta for the production of instant products, or for improvement of the cooking quality. Abecassis et al., (1986) noted, on pasta previously dried at $37^{\circ} \mathrm{C}$, an improvement of cooking quality and colour after hydrothermal treatment at $90{ }^{\circ} \mathrm{C}$ for short time.

The application of high temperature (HT) in the drying process (Abecassis et al., 1984; Anese et al., 1999) is the most noticeable innovation in pasta industry in recent years. The temperature usually reaches $70^{\circ} \mathrm{C}-80^{\circ} \mathrm{C}$ and in some cases more than $100^{\circ} \mathrm{C}$ (Güler et al., 2002). Under these conditions the objective of drying is not only lowering the moisture content from $30 \%$ to $12.5 \%$ w.b., but also causing transformations of the 
physicochemical characteristics (Zweifel et al., 2000). The main advantages of HT drying are the control of micro-organisms, the shortening of drying time and the improvement of the cooking quality (Dexter et al., 1981; De Stefanis and Sgruletta, 1990). The disadvantage is often a red colour development as a consequence of an increase in Maillard reactions (Anese et al., 1999; Zardetto et al., 2003).

The pasta quality has been shown to be highly influenced by starch gelatinisation and protein network formation (Resmini and Pagani, 1983; Fardet et al., 1998; Riva et al., 2000). During cooking, gelatinisation and formation of the protein network occur simultaneously which confers the viscoelastic characteristics to the cooked product (Feillet, 1984; Riva et al., 1991).

For rapid evaluation of cooking and processing properties of cereal products, the Rapid Visco-Analyser (RVA) is commonly used to measure the viscosity of starch-based materials over a heating-holding-cooling cycle to assess functional properties (Lai, 2001; Yunt et al., 1996). The viscographs of pasta, from the measurement of the changes in viscosity over time-temperature profile, can reflect the molecular changes of starch and functional properties of final product (Güler et al., 2002; Whalen et al., 1997; Panozzo and Mc Cormick, 1993).

Pasta colour is the first important quality characteristic that greatly influences consumer acceptance. Some authors showed that the colour depends mainly on two colour indexes: yellow index (b) and browning index (100-L) (Abecassis et al., 1984). These indexes are highly related to the genetic and agronomic characters, to the milling and to the pastification conditions (De Stefanis and Sgrulletta, 1990). The yellow colour is related to the presence of carotenoïd pigments and affected by lipoxygenases activity. Kobrehel and Abecassis (1985) showed that the browning of pasta was correlated to the 
peroxidasic activity of the semolina and that $\mathrm{HT}$ drying at $90{ }^{\circ} \mathrm{C}$ decreases this activity and induces an improvement of pasta colour.

The purpose of the present work is to study the effect of a recent hydrothermal process: the Instantaneous Controlled Pressure Drop (DIC) as a pre-treatment on freshly extruded pasta before drying. The DIC process is based on the thermomechanical effect induced by an abrupt transition from high steam pressure to a vacuum (Rezzoug et al., 2000). The most important parameters of this process are the steam pressure which determines the treatment temperature, the processing time and the vacuum pressure. The vacuum level is limited by the power of the vacuum pump. For this reason, we have fixed the pressure at its lowest value (50 mbar). Moreover it's the difference between the high pressure level and the vacuum which determines the amount of steam generated by flash vaporization and thus the intensity of the mechanical constraints responsible for the micro-alveolation phenomenon.

The effect of the two selected process variables (steam pressure level and processing time) was studied according to the characteristics of pasta by using hydration test, Rapid Visco Analyser (RVA) measurements, colour and scanning electron microscopic observations. 


\section{2: Materials and methods}

\section{1: Raw material}

Commercial fresh pasta (1.5 mm thickness) from a single commercial source (Panzani) was used in all experiments. The delay between the pasta processing and experiments was about 4 days during which the samples were conditioned in sealed bags at $4{ }^{\circ} \mathrm{C}$. The "tagliatelle" pasta shape, was composed from semolina of durum wheat, water and fresh eggs at a rate of $140 \mathrm{~g} / \mathrm{kg}$ of semolina.

\subsection{Methods}

\subsection{1: DIC equipment}

Figure 1 is a schematic representation of the used equipment. The DIC equipment is composed of three main elements:

- The processing vessel (2) where the samples were placed and treated.

- The vacuum system which consists mainly of a vacuum tank (4) with a volume 130 fold greater than the processing vessel and a vacuum pump (5).

- A pneumatic valve (3) that separates the processing vessel from the vacuum tank.

\subsection{2: Procedure of DIC hydrothermal treatment}

The fresh pasta was treated in the processing vessel in which a vacuum of 50 mbar was established through a short communication with the vacuum tank (Fig 2b). The initial vacuum is carried out to facilitate the diffusion of steam into pasta. Consequently, the time necessary for the temperature of the pasta to reach that of the steam is reduced. Saturated steam was then introduced into the vessel at fixed pressure level (Fig. 2c) and maintained for a predetermined time (Fig. 2d). This step is followed by a sudden decompression towards vacuum (Fig. 2e). The rapid transition of pressure inside the 
processing vessel induces a rapid cooling of pasta which passes in less than 1 second from $100-144{ }^{\circ} \mathrm{C}$ (according to the steam pressure condition) to about $30^{\circ} \mathrm{C}$. The equilibrium after pressure dropping depends on operating conditions: the higher the steam pressure level, the higher the equilibrium pressure. The steam generated by flash vaporization after the decompression to a vacuum produces a micro-texturation which is closely linked to a complex process of micro-alveolation. This process depends on the difference in pressure (or temperature) between the two thermodynamic equilibrium states before and after decompression. After the vacuum phase, atmospheric air is injected to return to atmospheric pressure (Fig. 2f) and to recover the product.

The feed of the treatment vessel was typically $300 \mathrm{~g}$. After treatment the pasta was airdried $\left(50{ }^{\circ} \mathrm{C}\right)$ in oven (Memert 700$)$ to $12 \%$ w.b..

\subsection{3 : Moisture content}

Moisture content of milled pasta was determined from the loss of weight during drying in a forced-air oven at $105^{\circ} \mathrm{C}(\mathrm{AACC}, 1995)$. The moisture content of the pasta before DIC treatment was $28.7 \%$ w.b. and passed to about $29.8 \%$ after the treatment for all samples.

\subsection{4 : Hydration test}

The test consists in hydrating $2.5 \mathrm{~g}$ of DIC treated pasta after drying, with 1 litre of distilled water at $100^{\circ} \mathrm{C}$ or $20{ }^{\circ} \mathrm{C}$. These temperatures were maintained constant during the test. During 20 minutes, the pasta was weighed at regular intervals (MaacheRezzoug and Allaf, 1999). The mass ratio between hydrated and unhydrated pasta $\left(\mathrm{W}_{\mathrm{i}} / \mathrm{W}_{0}\right)$ was calculated. $\mathrm{W}_{\mathrm{i}}$ and $\mathrm{W}_{0}$ are the mass of hydrated $\left(\mathrm{T}=20^{\circ} \mathrm{C}\right)$ or cooked $(\mathrm{T}=$ $100{ }^{\circ} \mathrm{C}$ ) pasta at various times and unhydrated pasta respectively. 
The optimal cooking time (OCT) corresponds to the occurrence of complete gelatinisation of the starch and the disappearance of the white central core of the pasta. After observation and tasting of pasta, OCT for untreated sample was estimated at 7 minutes. From figure $3-a$, it can be seen that 7 minutes of cooking time corresponds to a mass ratio $\mathrm{W} / \mathrm{W}_{\mathrm{o}}=2.4$. This value was taken as a reference to estimate OCT for treated pasta, and was thus defined as the time taken by the treated pasta to reach the optimal absorption (ratio=2).

\subsection{5 : Pasting properties}

Pasting properties of ground pasta sample were determined using a Rapid Visco Analyser (RVA 3C, Newport Scientific, Sydney, Australia). Four grams of ground pasta [250-500 $\mu \mathrm{m}]$ at $14 \%$ moisture basis was mixed with distilled water $(25 \mathrm{ml})$ in disposable aluminium sample cup. The mix was then homogenized and introduced in the instrument. A programmed heating and cooling cycle was used, the suspension was held at $25{ }^{\circ} \mathrm{C}$ for $6 \mathrm{~min}$, heated to $95{ }^{\circ} \mathrm{C}$ in $7 \mathrm{~min}$ at the rate of $10{ }^{\circ} \mathrm{C} / \mathrm{min}$. The temperature was held at $95{ }^{\circ} \mathrm{C}$ for 6 min, cooled to $25{ }^{\circ} \mathrm{C}$ in 7 min and then held at 25 ${ }^{\circ} \mathrm{C}$ for 6 min. The number of replication tests used in each case was two and the viscosity was expressed in $\mathrm{cP}$.

From the RVA profile, the viscosity at 10 minutes $\left(\mathrm{V}_{10}\right)$ measured at $66{ }^{\circ} \mathrm{C}$ was measured. The final or cold paste viscosity (CPV) i.e., viscosity at the end of the cycle at $25{ }^{\circ} \mathrm{C}$ and setback viscosity (SB) i.e., CPV-HPV (hot paste viscosity i.e., minimum viscosity during stirring at $95^{\circ} \mathrm{C}$ ) were calculated.

\subsection{6 : Pasta colour}

The colorimetric analyses were carried out on ground DIC treated samples [250-500

$\mu \mathrm{m}$ ]. CIELAB parameters L*, $\mathrm{a}^{*}$ and $\mathrm{b}^{*}$ were measured using a Hunter Lab D65-10 
Reflectance Colorimeter. The $\mathrm{L}^{*}$ value expressed the brightness of the sample with 100 as perfect white and 0 as black. A higher $\mathrm{L}^{*}$ indicates a brighter sample. Values of $\mathrm{a}^{*}$ and $\mathrm{b}^{*}$ indicated respectively the red-green and yellow-blue chromaticity. Positive $\mathrm{a}^{*}$ and $\mathrm{b}^{*}$ values expressed an increasing of redness and yellowness. The results are the average of three replications.

\subsection{7 : Scanning electron microscopy}

Scanning electron micrographs of the control sample and treated pasta were taken with a Jeol 5410 LV SEM. The samples were first splutter-coated with a thin gold film using a Cressington metallizer.

\subsection{8 : Experimental design}

A central composite rotatable design with two independent variables and five levels were used. For the two variables, the design yielded 12 experiments with four $\left(2^{2}\right)$ factorial points, four extra points (star points) to form central composite design and four central points for the replications. The experiments were run in random order to minimize the effects of unexpected variability in the observed responses due to extraneous factors. The experimental range and the central point were based on the results of preliminary trials. Table 1 lists the independent variables and the coded factor levels.

$$
\eta=\beta_{0}+\beta_{1} X_{1}+\beta_{2} X_{2}+\beta_{11} X_{1}^{2}+\beta_{22} X_{2}^{2}+\beta_{12} X_{1} X_{2}
$$

According to the statistical method, a second order polynomial function (Eq.1) was assumed to approximate the considered response. The coefficients of the polynomial equation are represented by $\beta_{0}$ (constant term), $\beta_{1}$ and $\beta_{2}$ (first order terms), $\beta_{11}$ and $\beta_{22}$ (second order terms) and $\beta_{12}$ (interaction involving the variables $X_{1}$ and $X_{2}$ ). The steam pressure level is denoted by $\mathrm{X}_{1}$ and the processing time by $\mathrm{X}_{2}$. 
The contour plots were obtained by using the design analysis procedure of Statgraphics Plus for Windows, (4.1 version). They were generated for each pasta quality by using the predicted values obtained by Eq. (1).

The relationships between the responses (absorption characteristics, RVA and colour values) and the processing parameters were judged by finding the correlation coefficients $\left(\mathrm{R}^{2}\right)$; the significance of the p-values was decided at a probability level of $0.01,0.05$ and 0.1

\section{3: RESULTS AND DISCUSSION}

\subsection{Water absorption}

Figure 3 shows the water absorption kinetic curves at 100 and $20^{\circ} \mathrm{C}$ for the raw and DIC treated pasta. It appears that the DIC treatment modified the behavior of pasta during the absorption process.

\subsubsection{Absorption kinetics at $100^{\circ} \mathrm{C}$}

The absorption kinetics (Fig. 3-a) showed that pasta hydrates rapidly up to $2 \mathrm{~min}$ of hydration time. The mass ratio $\mathrm{W} / \mathrm{W}_{\mathrm{o}}=2.4$ increased and reached the saturation from 12 min and the maximum absorption is obtained for the test carried out at $3.5 \mathrm{bar} / 15 \mathrm{sec}$ followed by the samples treated at $2.5 \mathrm{bar} / 25 \mathrm{sec}$. The statistical analysis indicates that the processing pressure had a significant effect on the absorption parameters (Table 3 ). The higher the processing pressure the higher the hydration rate of pasta. The low pressures $(\leq 1.5$ bar) do not exert any influence on the water absorption; the values of $\mathrm{W} / \mathrm{W}_{\mathrm{o}}$ are almost identical to that of raw pasta. In contrast, the treatment at $\mathrm{p}>3.5 \mathrm{bar}$ and $t>15 \mathrm{sec}$ seems to be excessive processing conditions and provided a very sensitive sample to overcooking. For these conditions, a marked deliquescence of pasta and a 
large amount of solid loss in water for important cooking times were observed. The reduction in $\mathrm{W} / \mathrm{W}_{\mathrm{o}}$ is probably due to this solid loss and suggested that for high conditions of DIC treatment $\left(\mathrm{p}>3.5 / \mathrm{T}>138{ }^{\circ} \mathrm{C}\right)$, the protein network which retained its integrity during cooking is disrupted.

The optimal cooking time (OCT) for treated pasta, evaluated by sensorial analysis, was reduced as a consequence of the improvement of water absorption. The presence of mico-alveolation in the structure favors the internal diffusion of water. The cooking time of untreated pasta was 7 min corresponding to a ratio of 2.4 , while for the same ratio OCT was less than $1 \mathrm{~min}$ for pasta treated at pressure between 2.5/15 $\mathrm{sec}$ and 3.5 bar/15 sec (Table 2). Compared to $7 \mathrm{~min}$, the cooking time of untreated sample, the pasta treated at $3.5 \mathrm{bar} / 15 \mathrm{sec}$ has a ratio of 3.5 that corresponds to overcooking stage. In these conditions, the important water absorption induced an increase of the cooked volume and makes the pasta softer, thus reducing firmness. According to Del Nobile and Massera (2000), the organoleptic changes of pasta during overcooking are strongly related to the rate at which water molecules penetrate the pasta matrix once the optimal cooking conditions are reached.

\subsubsection{Kinetics absorption water of $20^{\circ} \mathrm{C}$}

To understand the effect of DIC treatment on starch modifications it is convenient to analyze the water absorption at ambient temperature $\left(20^{\circ} \mathrm{C}\right)$. In fact, the cooking at $100^{\circ} \mathrm{C}$ can mask the effect of DIC treatment whereas absorption at $20^{\circ} \mathrm{C}$ allows separation of the two phenomena knowing that the native starch granules have the characteristic to be insoluble in cold water. From kinetics obtained at $20^{\circ} \mathrm{C}$ (Fig. 3-b), it can be noted that the mass ratio $\left(\mathrm{W} / \mathrm{W}_{\mathrm{o}}\right)_{20}{ }^{\circ} \mathrm{C}$ depends not only on the steam pressure level but also on the processing time, contrary to the absorption kinetics at $100^{\circ} \mathrm{C}$. The 
heating which accompanies the cooking at $100{ }^{\circ} \mathrm{C}$ should certainly mask the effect of the processing time. At fixed processing time, the higher the pressure level, the higher the absorption capacity and at fixed pressure level, the higher the processing time, the higher the adsorption capacity.

From figure $3-\mathrm{b}$, it is clear than at $20{ }^{\circ} \mathrm{C}$ the absorption spectrum is wider that the one obtained at $100{ }^{\circ} \mathrm{C}$ (Fig. 3 -a). The raw and the pasta treated at low pressures $(\leq 1.5 \mathrm{bar})$ exhibit a low absorption capacity. This is due to a limited moisture content of fresh pasta $(28.7 \%)$ for causing a complete gelatinisation of starch at low processing conditions $\left(\mathrm{p} \leq 1.5\right.$ bar $\left./ \mathrm{T}<120^{\circ} \mathrm{C}\right)$. Absorption, even moderate, of the untreated pasta proves the existence of some damage of the starch granules caused during the extrusion phase of pasta processing.

For higher pressures $(\geq 2.5$ bar $) \mathrm{W} / \mathrm{W}_{\mathrm{o}}$ measured at 5 minute of hydration time is almost identical to the ratio obtained at $100^{\circ} \mathrm{C}$ (Table 2). The absorption at $20^{\circ} \mathrm{C}$ may confirm the complete gelatinisation of starch granules.

\subsection{RVA parameters}

The statistical analysis (Table 3) indicates that the pressure level and processing time had a significant linear effect on $\mathrm{V}_{10}$ while for the two other RVA parameters; only the steam pressure level was significant. The viscosity measured at $10 \mathrm{~min}\left(\mathrm{~V}_{10}\right)$ increases strongly with steam pressure and to a lesser extent with processing time (Table 2). The maximal value of $\mathrm{V}_{10}(2659 \mathrm{cP})$ was obtained for the pasta treated at 3.9 bar and $25 \mathrm{sec}$ while it was only $146 \mathrm{cP}$ for the raw pasta. The high viscosity measured at 10 minute (at $66^{\circ} \mathrm{C}$ ) showed a typical hydration property of pregelatinized starch products. Lai (2001) reported a similar observation for hydrotreated rice flour. The gelatinisation is accompanied by a disruption of the molecular order as a result of loss of the starch 
granule structure and disruption of crystallinity (Cooke and Gidley, 1992). These molecular changes imply cold soluble properties by creating high viscosity at low temperature.

A recent study (Loisel et al., 2003) on native maize starch treated at residual moisture content ( $12 \%$ w.b.) by DIC showed that the two process parameters (steam pressure and processing time) have influence on the degree of gelatinisation of starch. The occurrence of partial gelatinisation was clearly attested by the decrease of enthalpy measured by differential scanning calorimetry (DSC) and a loss of birefringence under polarized light, for 2.7 bar and 5 minutes of processing time. For the same native maize starch a total gelatinisation was observed for 3 bar and processing time higher than 15 minutes, (Zarguili et al., 2004).

DIC treated pasta displayed a lower final viscosity (CPV) than the one of untreated sample. The CPV value for treated pasta varied between $11459 \mathrm{cP}(1 \mathrm{bar} / 25 \mathrm{sec})$ and $10560 \mathrm{cP}(3.9 \mathrm{bar} / 25 \mathrm{sec})$ while it was $11581 \mathrm{cP}$ for the raw pasta. Yue et al., (1999) suggested that the lower final viscosities of HT-dried pasta samples could be partially explained by greater amylose-lipid complex formation that may have restricted recrystallization of amylose during cooling. Güler et al., (2002) confirmed these observations by X-ray diffraction.

As the mixture pasta-water is cooled, re-association between starch molecules, especially amylose, occurs to a greater or lesser degree (Zweifel et al., 2000). This phase of the pasting curve is commonly referred to as the setback region (SB), and involves retrogradation, or re-ordering of the starch molecules. The pressure level had a strong effect on SB which diminished from 8655 to $7512 \mathrm{cP}$, when this parameter increased 
from 1 to 3.9 bar, suggesting that increasing of steam pressure leads to a decreasing of starch retrogradation capacity.

\subsection{Colour parameters}

For the three colour parameters, it can be seen that the processing pressure and the interaction between the two process parameters are significant (Table 3). The analysis of the interactions shows that the steam pressure has a strong effect only at low level of processing time. At 15 seconds, the brightness $\left(\mathrm{L}^{*}\right)$ increased from 79.6 to 82.1 when the steam pressure level passed from 1.5 to 3.5 bar, respectively (Table 2). Steam pressure of 3.5 bar associated with a low processing time (15 seconds) seems to maximize the brightness of treated pasta.

The improvement of the brightness observed for pressures ranging between 1.5 and 3.5 bar (corresponding to $110-138{ }^{\circ} \mathrm{C}$ ) suggests a probable inhibition of peroxidase activity. These results are in accordance with those of De Stefanis and Sgrulletta (1990) obtained for pasta dried at $90{ }^{\circ} \mathrm{C}$ and short time. Kobrehel and Abecassis (1985) suggest a rapid subjecting of pasta to high temperature, just after pasta manufacturing in order to inhibit the enzymatic activities and improve the pasta colour. For the DIC treatment, the rapid release of steam pressure towards vacuum induces a rapid cooling and thus stops the thermal degradation reactions.

When the pressure increased from 1.5 to $3.5 \mathrm{bar}$, $\mathrm{a}^{*}$ varied from 3.19 to 1.71 for a processing time of 15 seconds while it diminished only from 2.7 to 2.3 for a processing time of 35 seconds and a same variation of pressure.

The $b^{*}$ values varied between 30.2 and 25 when the steam pressure increased from 1.5 to 3.5 bar for 15 seconds of processing time. The variation was very weak when the 
processing time is fixed at 35 seconds. The decreasing of yellowness is probably due to the micro-alveolation of internal structure observed by SEM (section 3.5) of the treated pasta causing a small increase in apparent volume.

\subsection{Statistical analysis}

From table 3, the linear, quadratic and interaction effects can be estimated from the Fisher test (F-ratio). This value tests the statistical significance of each effect by comparing the mean square against an estimate of the standard error. It can be seen that the processing pressure has a strong linear effect on the hydration characteristics and RVA parameters and to a lesser extent on pasta colour. Steam pressure level affected all response parameters with $p$-value $\leq 0.05$ except $\mathrm{L}^{*}$ and $\mathrm{b}^{*}$ which become significant for $\mathrm{p}$-value $\leq 0.1$. The processing time affects only $\mathrm{W} / \mathrm{W}_{\mathrm{o}}$ at $20^{\circ} \mathrm{C}$ and $\mathrm{V}_{10}$, p-value was respectively less than 0.01 and 0.05 . For the three hydration characteristics, quadratic effects of the steam pressure level were identified as significant with $p$-value $\leq 0.05$.

The regression equations used to generate the contour plots are shown in table 4. High $\mathrm{R}^{2}$ values and model significance were obtained for all quality factors tested, except for the two first colour parameters $\left(\mathrm{L}^{*}\right.$ and $\left.\mathrm{a}^{*}\right)$ for which $\mathrm{R}^{2}$ was 0.68 in the two cases. The selected contour plots are presented in figure 4, including three representative parameters of cooking quality $(\mathrm{OCT})$, pasting $\left(\mathrm{V}_{10}\right)$ and colour properties ( $b^{*}$ value). From this figure, it can be seen that the optimal cooking time decreased as the pressure level increased. To obtain a quick cooking pasta of 1 minute, DIC treatment at 2.5 bar steam pressure during 10 seconds is required, according to the developed regression model $\left(\mathrm{R}^{2}=0.98\right)$. The contour plots for $\mathrm{V}_{10}$ show that the viscosity of hydrothermally treated pasta increased with pressure level and the magnitude of this increase is more 
marked for the highest values. According to the developed regression model $\left(\mathrm{R}^{2}=0.89\right)$ the pasta yellowness ( $b^{*}$ value) showed an improvement trend at lower process conditions. The $\mathrm{b}^{*}$ value varied from 33 to 29 when the pressure dropped from 1.2 to 2.5 bar. DIC treatment at pressures around 2.5 bar allows to maintain the same pasta yellowness as that of untreated pasta (29.1).

\subsection{Scanning electron microscopy}

Microscopic examinations of cross sections of treated and untreated pasta after drying showed the impact of the DIC treatment on the internal structure and the state of the

starch (Figure 5). A more porous structure was observed for treated pasta (photos B, C and D) with starch granules more or less intact according to conditions of the treatment. In fact, the sample treated at 4 bar during 10 seconds (photo D) has an alveolated texture with pores of important size without visible starch granules. Such a structure would facilitate a rapid water penetration during cooking. In contrast, a photo of untreated pasta (photo A) revealed a very compact structure.

\section{4: Conclusion}

The results of this study have shown that cooking quality, pasting properties and colour characteristics are directly influenced by the conditions of DIC treatment. The steam pressure level had the most influence on pasta quality, since it had a significant effect on all response variables investigated. Under studied pressure conditions, the fresh pasta was undergoing physical modifications resulting in the improvement of water absorption, and thus cooking time and colour quality. Increasing of pressure level induces a high apparent viscosity. The microscopy observations showed that the DIC treatment affects the internal structure and the state of starch granules. The rapid water 
evaporation from the pasta samples creates porous spaces in an internal structure that favours water diffusion and promotes a rapid water uptake during cooking and consequently, a shortening of cooking time. 


\section{REFERENCES}

Abecassis, J., Alary, R., Feillet, P., 1984. Influence des températures de séchage sur l'aspect et la qualité culinaire des pâtes alimentaires. Industries des céréales 31, 13-18.

Abecassis, J., Chevalier, F., Ait-mouh, O., Matencio, F., Faure, J., Feillet, P. 1986. Amélioration de la qualité des pâtes alimentaires par traitement thermique des produits secs. Industries des Céréales 41, 13-17.

American Association of Cereal Chemists. 1995. Approved Methods of the AACC, $8^{\text {th }}$ ed. Method No. 44-15A. Approved 10-30-75, Revised 10-28-81, 10-26-94. The Association : St. Paul, MN.

Anese, M., Nicoli, M.C., Massini, R., Lerici, C.R. 1999. Effects of drying processing on the Maillard reaction in pasta. Food Research International 32, 193-199.

Cooke, D., Gildey, M.J. 1992. Loss of crystalline and molecular order during starch gelatinisation: origin of enthalpic transition. Carbohydrate Research 227, 103-112.

De Stefanis, E., Sgrulletta, D. 1990. Effects of high-temperature drying on technological properties of pasta. Journal of Cereal Science 12, 97-104.

Debbouz, A., Doetkott, C. 1996. Effect of process variables on spaghetti quality. Journal of Cereal Chemistry 73, 672-676.

Del Nobile, M.A., Massera, M. 2000. Modeling of water sorption kinetics in spaghetti during overcooking. Journal of Cereal Chemistry 77, 615-619.

Dexter, J.E., Matsuo, R. R., Morgan, B.C. 1981. High temperature drying : Effect on spaghetti properties. Journal of Food Sciences 46, 1741-1746.

Dexter, J.E., Matsuo, R.R., Morgan, B.C. 1983. Spaghetti stickiness : some factors influenncing stickiness and relationship to other cooking quality characteristics. Journal of Food Sciences 48, 1545-1551.

Fardet, A., Baldwin, P.M., Bertrant, D., Bouchet, B., Gallant, D.J., Barry, J.-L. 1998. Textural images analysis of pasta protein networks to determine influence of technology processes. Journal of Cereal Chemistry 75, 699-704.

Favier, J., Samson, M.-F., Aubled, C., Morel, M.-H., Abecassis J. 1996. Suivi de la cinétique thermique d'insolubilisation des protéines de la pâte alimentaire par chromatographie d'exclusion-diffusion haute performance. Science des Aliments 16, 573-591.

Feillet, P. 1984. The biochemical basis of pasta cooking quality. Its consequences for durum wheat breeders. Science des Aliments 4, 551-566.

Fortini, S. 1988. Durum, Chemistry and Technology. In: G. Fabrini and C. Lintas. Eds. American Association of Cereal Chemists, St. Paul, MN., pp.229-233.

Güler, S., Köksel, H., Ng, P.K.W. 2002. Effects of industrial pasta drying temperatures on starch properties and pasta quality. Food Research International 35, 421-427. 
Kobrehel, K., Abecassis J. 1985. Influence de la température de séchage des pâtes alimentaires sur l'activité et la composition des peroxydases en relation avec la couleur des produits. Lebensmittel-Wissenschaft und Technologie 18, 277-280

Lai, H. -M. 2001. Effects of hydrothermal treatment on the physicochemical properties of pregelatized rice flour. Food Chemistry 72, 455-463.

Loisel, C., Maache-Rezzoug, Z., Esneault C., Doublier J.L. 2003. Effect of instantaneous controlled pressure drop on the physical properties of maize starch. Paper presented at the $9^{\text {th }}$ Congress of the French Society of Chemical Engineering, SaintNazaire, France, 9-11 September 2003. Published (CD-ROM.) in "Récents Progrès en Génie des Procédés" 190-197.

Maache-Rezzoug, Z., Allaf, K. 1999. Influence of instantaneous controlled decompression treatment on texturation \& cooking time of the pasta. In Lavoisier (Eds), Paris, Récents Progrès en Génie des Procédés, 13, 393-400.

Panozzo J.F., Mc Cormick K.M. 1993. The Rapid Viscoanalyser as a method of testing for noodle quality in a wheat breeding program. Journal of Cereal Science 17, 25-32.

Resmini, P., Pagani M.A. 1983. Ultrastructure studies of pasta: a review. Food microstructure 2, 1-12.

Rezzoug, S.A., Maache-Rezzoug, Z., Mazoyer, J., Jeannin, M., Allaf, K. 2000. Effect of instantaneous controlled pressure drop proccess on hydration capacity of scleroglucan. Optimisation of operating conditions by response surface methodology. Journal of Carbohydrate polymers $42,73-84$.

Riva, M., Fessa, D., Schiraldi, A. 2000. Starch retrogradation in cooked pasta and rice. Cereal Chemistry 77, 433-438.

Riva, M., Piazza, L., Shiraldi, A. 1991. Starch gelatinization in pasta cooking: Differential flux calorimetry investigations. Cereal Chemistry 68, 622-627.

Whalen, P.J., Bason, M.L., Booth, R.I., Walker, C.E., Williams, P. J. 1997. Measurement of extrusion effects by viscosity profile using the Rapid ViscoAnalyser. Cereal Foods World 42, 469-475.

Wood, J. A., Batey, I.L., Hare, R.A., Sissons, M.J. 2001. A comparison of Australian and imported spaghetti. The $34^{\text {th }}$ Annual AIFST, Food Australian 53, 349-354.

Yue, P., Rayas-Duarte, P., Elias, E. 1999. Effect of drying temperature on phisicochemical properties of starch isolated from pasta. Cereal Chemistry 76, 541-547.

Yunt, S. -H., Quail, K., Moss, R. 1996. Physicochemical properties of australian wheat flours for white salted noodles. Cereal Science 13, 181-189.

Zardetto, S., Dalla Rosa, M., Di Fresco, S. 2003. Effect of different heat treatment on the furosine content in fresh filled pasta. Food Research International 36, 877-883.

Zarguili, I., Maache-Rezzoug, Z., Loisel, C., Doublier, J.L. 2004. Study of the effect of hydrothermal process conditions on the properties of maize starch. to be published (CDROM) of the $16^{\text {th }}$ International Congress of Chemical engineering. CHISA 23-28 august 2004. Prague. Czech Republic. 
Zweifel, C., Conde-Petit, B., Escher, F. 2000. Thermal modifications of starch during high-temperature drying of pasta. Cereal Chemistry 77, 645-651. 


\section{Figure Captions}

Figure 1. Schematic of apparatus for pasta treatment by DIC. 1. Boiler, 2. Autoclave (stainless steel). 3.Pneumatic valve, 4. Vacuum container, 5. Vacuum pump, 6. Extract container.

Figure 2. Typical pressure-time profile of a DIC processing cycle. (a) sample at atmospheric pressure; (b) establishment of a vacuum; (c) steam injection to reach the selected pressure; (d) treatment time; (e) pressure drop; (f) atmospheric pressure for the recovery of sample.

Figure 3. Cooking $\left(\mathrm{T}=100^{\circ} \mathrm{C}\right)$ and absorption $\left(\mathrm{T}=20^{\circ} \mathrm{C}\right)$ kinetics of tagliatelle pasta treated by DIC at different processing conditions and untreated pasta.

Figure 4. Contour plot of optimum cooking time (OCT) of pasta, viscosity at 10 minutes $\left(\mathrm{V}_{10}\right)$ and yellowness $\left(\mathrm{b}^{*}\right.$ value) as a function of steam pressure level and processing time.

Figure 5. Scanning electron micrographs of untreated pasta (A) and DIC treated pasta at $2 \mathrm{bar} / 10 \mathrm{sec}(\mathrm{B}), 2 \mathrm{bar} / 20 \mathrm{sec}(\mathrm{C})$ and $4 \mathrm{bar}$ and $10 \mathrm{sec}(\mathrm{D})$. 
Table 1: Coded levels for independent variables used in developing experimental data

\begin{tabular}{llllll}
\hline & \multicolumn{5}{c}{ Coded level } \\
\cline { 2 - 6 } & $-\alpha$ & -1 & 0 & 1 & $+\alpha$ \\
\hline Steam pressure level (bar) & 1.1 & 1.50 & 2.50 & 3.5 & 3.9 \\
Processing time (s) & 11 & 15 & 25 & 35 & 39 \\
\hline$\alpha$ (Axial distance) $\sqrt[4]{\mathrm{N}}, \mathrm{N}$ is the number of experiments of orthogonal design, i.e. \\
of the factorial design. In this case $\alpha=1.414 .11$ and 39 seconds are the \\
approximation of 10.86 and 39.14 seconds that correspond to the values of $-\alpha$ and $+\alpha$ for \\
processing time.
\end{tabular}


Table 2 : Experimental data and the observed responses values with different combinations of steam pressure level and processing time used in the randomized central composite rotatable design.

\begin{tabular}{|c|c|c|c|c|c|c|c|c|c|}
\hline \multirow{2}{*}{$\begin{array}{c}\text { Processing } \\
\text { Parameters } \\
\text { Steam pressure } \\
\text { level (bar)/time (s) }\end{array}$} & \multicolumn{3}{|c|}{ Absorption characteristics } & \multicolumn{3}{|c|}{ RVA parameters } & \multicolumn{3}{|c|}{ Pasta colour } \\
\hline & $\begin{array}{c}\mathrm{W} / \mathrm{W}_{0}{ }^{1} \text { at } \\
100^{\circ} \mathrm{C}\end{array}$ & $\begin{array}{l}\mathrm{OCT}^{2} \\
\text { (min.) }\end{array}$ & $\begin{array}{c}\mathrm{W} / \mathrm{W}_{0}{ }^{1} \text { at } \\
20^{\circ} \mathrm{C}\end{array}$ & $\begin{array}{l}\mathrm{V}_{10} \\
(\mathrm{cP})\end{array}$ & $\begin{array}{l}\mathrm{CPV} \\
(\mathrm{cP})\end{array}$ & $\begin{array}{l}\mathrm{SB} \\
(\mathrm{cP})\end{array}$ & $\mathrm{L}^{*}$ & $a^{*}$ & $\mathrm{~b}^{*}$ \\
\hline $3.5 / 15$ & 3.28 & 0.98 & 2.72 & 2339 & 10670 & 7643 & 82.1 & 1.71 & 25.0 \\
\hline $2.5 / 11$ & 3.20 & 1.0 & 2.09 & 960 & 10829 & 8109 & 80.0 & 2.69 & 29.1 \\
\hline $3.9 / 25$ & 2.68 & 3.0 & 3.0 & 2659 & 10560 & 7512 & 80.3 & 2.20 & 28.4 \\
\hline $2.5 / 39$ & 3.13 & 0.90 & 2.38 & 1502 & 10876 & 8029 & 80.2 & 2.47 & 28.2 \\
\hline $1.5 / 35$ & 2.57 & 3.8 & 1.69 & 398 & 10878 & 8285 & 80.3 & 2.68 & 28.6 \\
\hline $1.5 / 15$ & 2.40 & 5.0 & 1.42 & 241 & 11145 & 8388 & 79.6 & 3.19 & 30.2 \\
\hline $3.5 / 35$ & 2.86 & 1.7 & 2.95 & 2338 & 10608 & 7569 & 80.2 & 2.28 & 28.3 \\
\hline $1.1 / 25$ & 2.32 & 6.50 & 1.48 & 199 & 11459 & 8655 & 79.9 & 3.06 & 29.8 \\
\hline $2.5 / 25^{3}$ & 3.18 & 0.93 & 2.43 & 1238 & 10743 & 7996 & 80.9 & 2.28 & 27.3 \\
\hline Untreated & 2.20 & 7.0 & 1.43 & 146 & 11581 & 8604 & 80.3 & 3.15 & 29.1 \\
\hline $\begin{array}{l}\text { Mean absolute } \\
\text { error }\end{array}$ & 0.20 & 0.15 & 0.05 & 52 & 130 & 91 & 0.50 & 0.20 & 1.10 \\
\hline
\end{tabular}

${ }^{1}$ : measured at 5 min of absorption time $;{ }^{2}$ : OCT (optimal cooking time) was calculated at $\mathrm{W} / \mathrm{W}_{0}=2.4 ;^{3}$ : mean of four repetitions. 
Table 3 : Analysis of variance showing the effect of treatment variables as a linear term, quadratic and interaction (cross product) on the response parameters.

\begin{tabular}{|c|c|c|c|c|c|c|c|c|c|}
\hline \multirow[b]{2}{*}{$\begin{array}{c}\text { Independent } \\
\text { variables }\end{array}$} & \multicolumn{3}{|c|}{ Hydration characteristics } & \multicolumn{3}{|c|}{ RVA parameters } & \multicolumn{3}{|c|}{ Pasta colour } \\
\hline & $\begin{array}{c}\mathrm{W} / \mathrm{W}_{0}{ }^{1} \text { at } \\
100^{\circ} \mathrm{C}\end{array}$ & $\begin{array}{l}\mathrm{OCT}^{2} \\
\text { (min.) }\end{array}$ & $\begin{array}{c}\mathrm{W} / \mathrm{W}_{0}{ }^{1} \text { at } \\
20^{\circ} \mathrm{C}\end{array}$ & $\begin{array}{l}\mathrm{V}_{10} \\
\text { (cP) }\end{array}$ & $\begin{array}{l}\mathrm{CPV} \\
(\mathrm{cP})\end{array}$ & $\begin{array}{l}\text { SB } \\
(\mathrm{cP})\end{array}$ & $\mathrm{L}^{*}$ & $a^{*}$ & $b^{*}$ \\
\hline \multicolumn{10}{|l|}{ Linear } \\
\hline $\mathrm{X}_{1}$ & $11.6^{* *}$ & $149^{*}$ & $521^{*}$ & $451^{*}$ & $24.0^{*}$ & $140^{*}$ & $3.49^{* * *}$ & $28.0^{*}$ & $5.25^{\text {*** }}$ \\
\hline $\mathrm{X}_{2}$ & $\mathrm{~ns}$ & ns & $19.4^{*}$ & $6.80^{* * *}$ & ns & ns & $\mathrm{ns}$ & $\mathrm{ns}$ & ns \\
\hline \multicolumn{10}{|l|}{ Quadratic } \\
\hline $\mathrm{X}_{1}^{2}$ & $24.6^{*}$ & $206^{*}$ & $13.1^{* *}$ & $3.68^{* * * *}$ & $3.42^{* * *}$ & ns & ns & ns & ns \\
\hline $\mathrm{X}_{2}^{2}$ & ns & ns & $13.7^{*}$ & ns & ns & ns & ns & ns & ns \\
\hline \multicolumn{10}{|l|}{ Interaction } \\
\hline$X_{1} X_{2}$ & ns & $8.94^{* *}$ & ns & ns & ns & ns & $5.37^{* *}$ & $6.81^{* * *}$ & $4.50^{* * *}$ \\
\hline
\end{tabular}

$\mathrm{X}_{1}$ : steam pressure level $; \mathrm{X}_{2}$ : processing time ;

${ }^{1}:$ measured at 5 min of absorption time $;{ }^{2}:$ OCT calculated at $\mathrm{W} / \mathrm{W}_{0}=2.4 ;$

* : P-value $\leq 0.01,^{* *}:$ P-value $\leq 0.05 ;^{* * * *}:$ P-value $\leq 0.1 ;$ ns : not significant 
Table 4 : Regression equations describing the response of each quality parameter as a function of the significant effects retained in the models.

\begin{tabular}{|c|c|c|}
\hline Response parameters & Equation & $\mathrm{R}^{2}$ \\
\hline \multicolumn{3}{|c|}{ Hydration characteristics } \\
\hline $\mathrm{W} / \mathrm{W}_{0}{ }^{1}$ at $100{ }^{\circ} \mathrm{C}$ & $3.16+0.419 X_{1}-0.0872 X_{1}^{2}$ & 0.87 \\
\hline $\mathrm{OCT}^{2}(\min )$. & $1.11-2.77 X_{1}+3.65 X_{1}^{2}+0.960 X_{1} X_{2}$ & 0.98 \\
\hline $\mathrm{W} / \mathrm{W}_{0}{ }^{1}$ at $20^{\circ} \mathrm{C}$ & $2.43+1.18 \mathrm{X}_{1}+0.227 \mathrm{X}_{2}-0.208 \mathrm{X}_{1}^{2}-0.214 \mathrm{X}_{2}^{2}$ & 0.99 \\
\hline \multicolumn{3}{|l|}{ RVA parameters } \\
\hline $\mathrm{V}_{10}(\mathrm{cP})$ & $1238+1879 X_{1}+231 X_{2}-189 X_{1}^{2}$ & 0.99 \\
\hline $\mathrm{CPV}(\mathrm{cP})$ & $10744-504 X_{1}+213 X_{1}^{2}$ & 0.83 \\
\hline $\mathrm{SB}(\mathrm{cP})$ & $7997-769 X_{1}$ & 0.96 \\
\hline \multicolumn{3}{|l|}{ Pasta colour } \\
\hline $\mathrm{L}^{*}$ & $-81+0.741 X_{1}-1.30 X_{1} X_{2}$ & 0.68 \\
\hline$a^{*}$ & $2.28-0.774 X_{1}+0.540 X_{1} X_{2}$ & 0.68 \\
\hline $\mathrm{b}^{*}$ & $27.3-1.87 X_{1}+2.45 X_{1} X_{2}$ & 0.89 \\
\hline
\end{tabular}





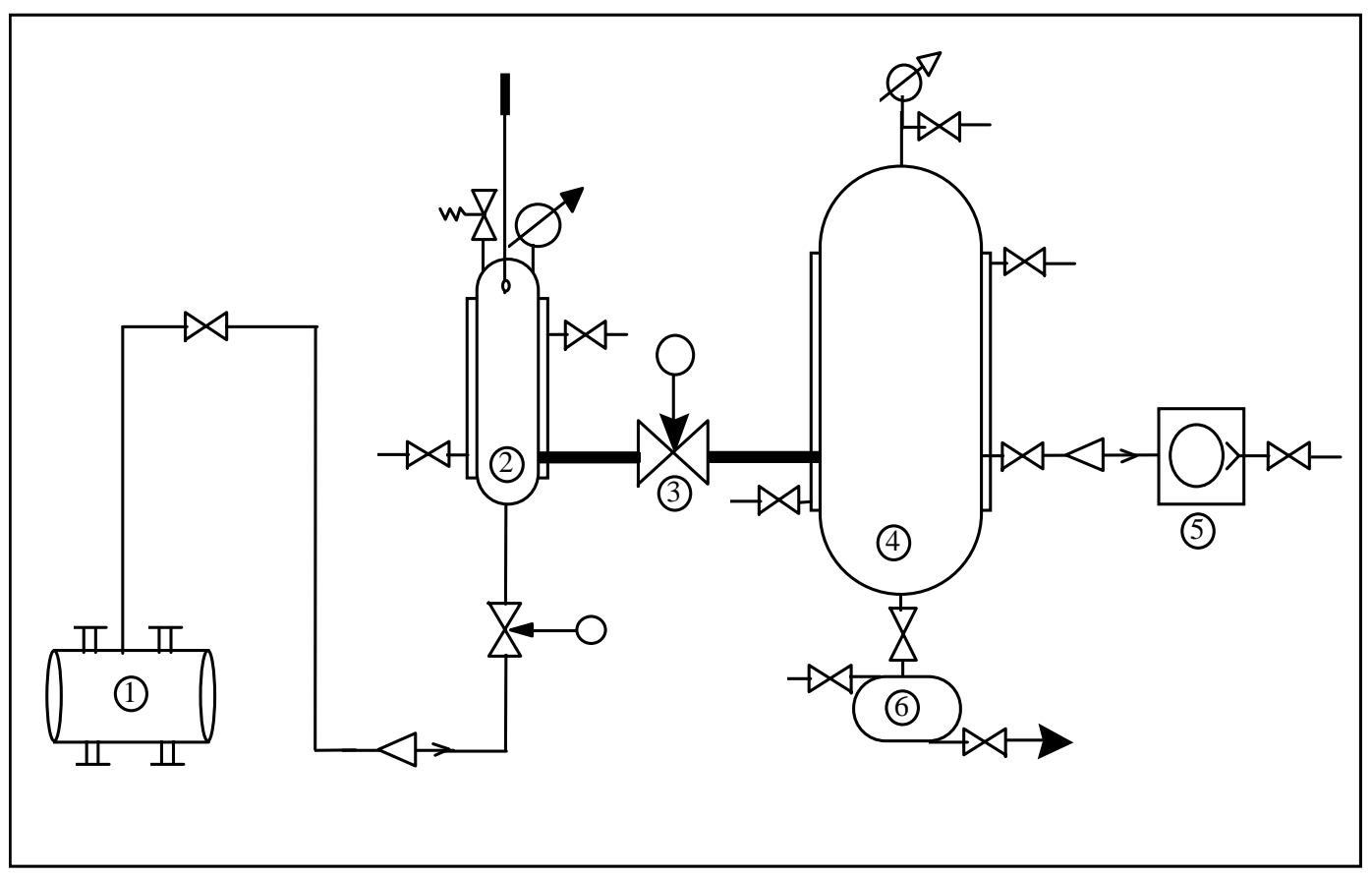

Fig.1 


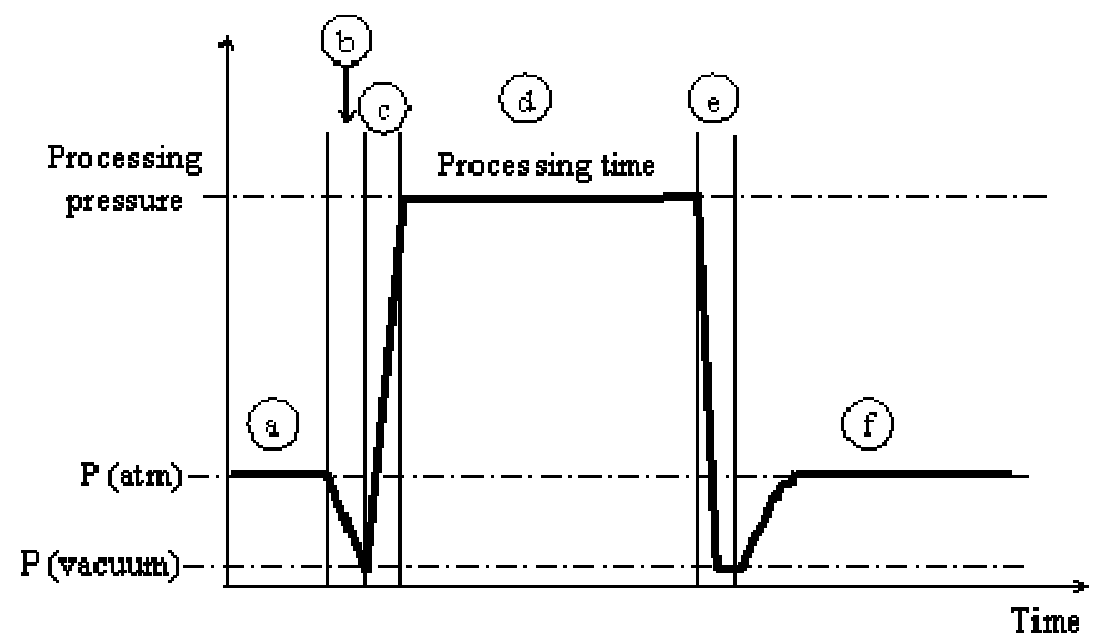

Fig. 2 

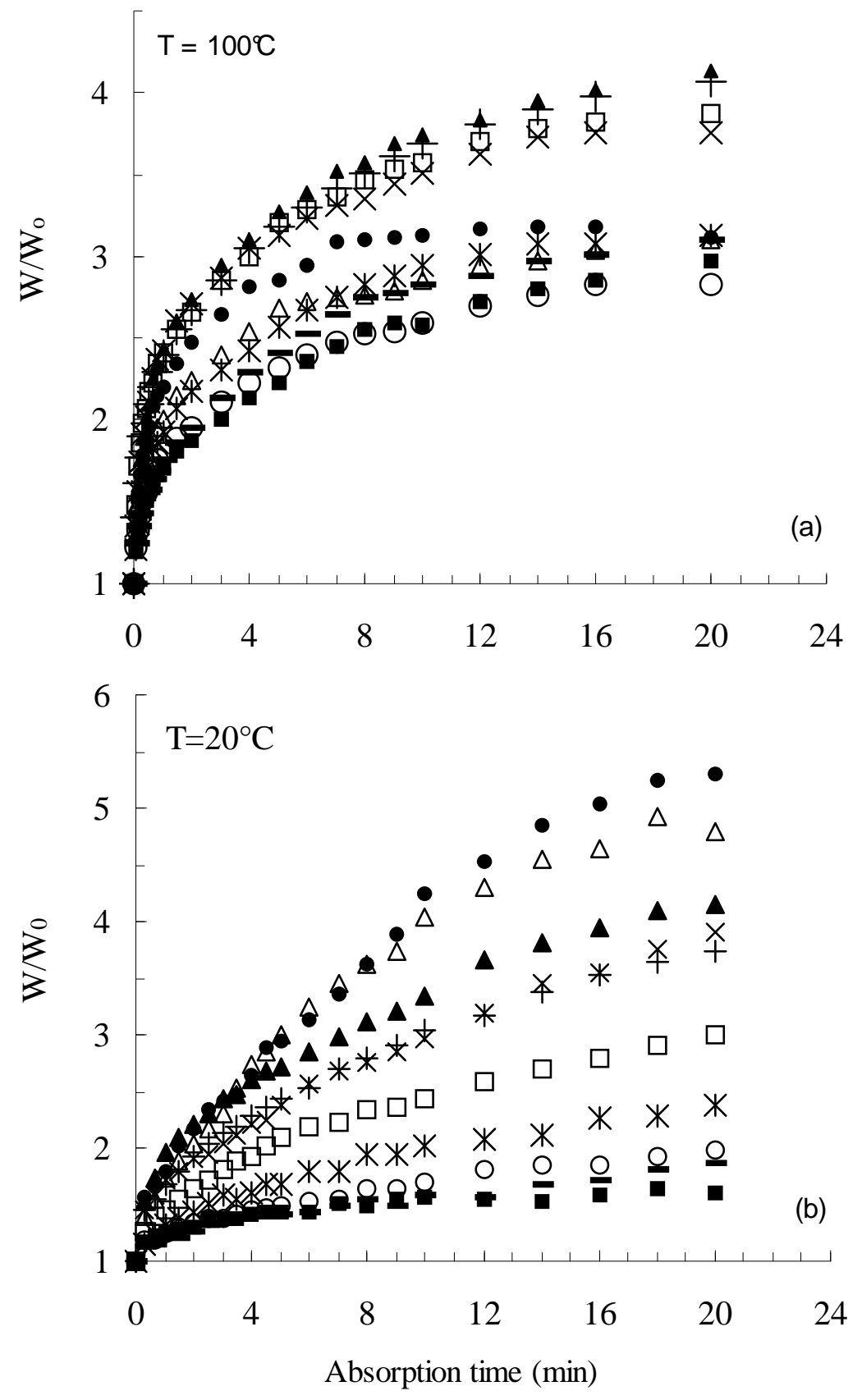

$\begin{array}{llll}\Delta 3.5 \mathrm{bar} / 15 \mathrm{~s} & \square 2.5 / 11 & \Delta 3.9 / 25 & \times 2.5 / 39 \\ * 1.5 / 35 & -1.5 / 15 & \bullet 3.5 / 35 & 01.1 / 25 \\ +2.5 / 25 & \square \text { untreated pasta } & \end{array}$

Fig. 3 

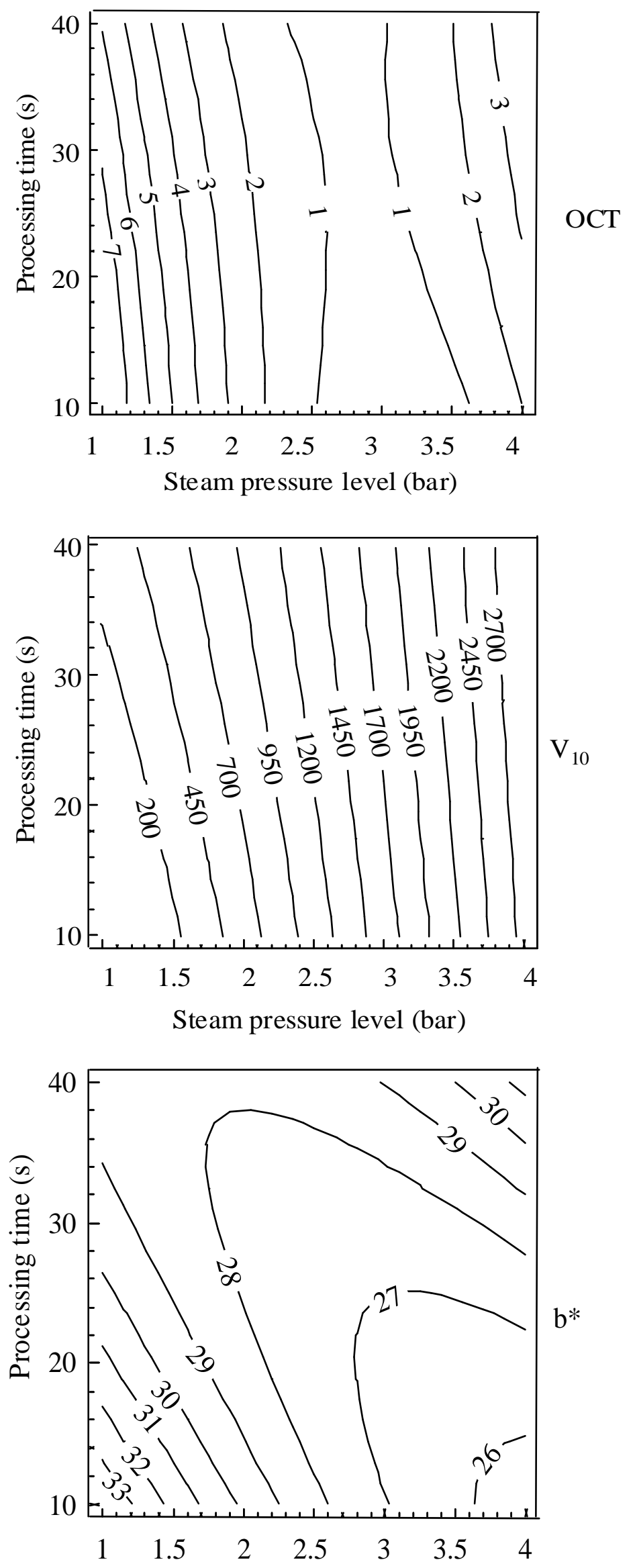

Steam pressure level (bar)

Fig. 4 


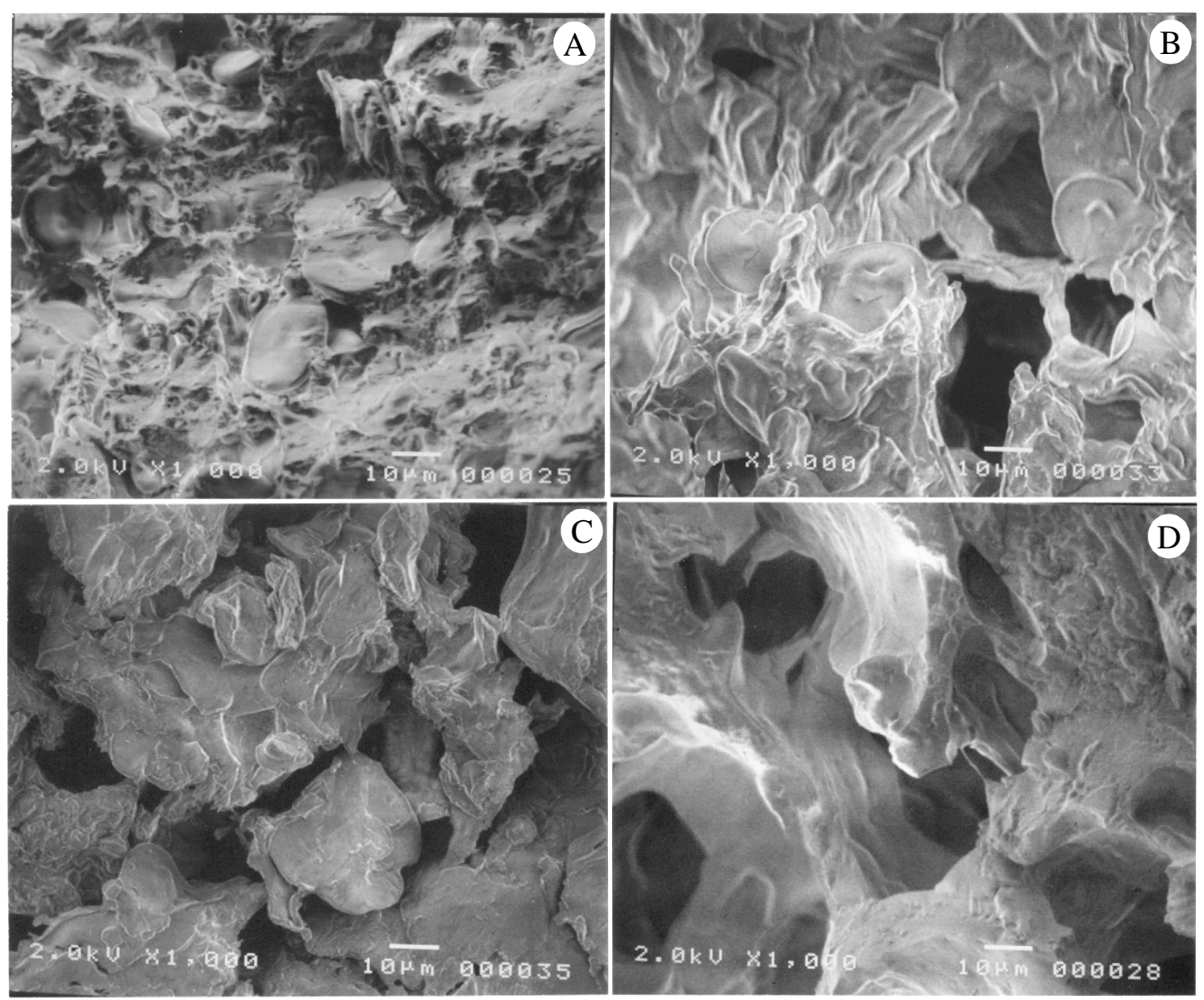

Fig. 5 